\title{
Viability of small preantral ovarian follicles from domestic cats after cryoprotectant exposure and cryopreservation
}

\author{
K. Jewgenow ${ }^{1 *}$, L. M. Penfold ${ }^{2}$, H. H. D. Meyer ${ }^{1}$ and D. E. Wildt ${ }^{2}$ \\ ${ }^{1}$ Institute for Zoo Biology and Wildlife Research, PF 1103, D-10252 Berlin, Germany; and ${ }^{2}$ Conservation \\ and Research Center, National Zoological Park, Smithsonian Institution, Front Royal, VA 22630, USA
}

\begin{abstract}
About 1500 preantral follicles can be recovered from a single cat ovary by mechanical dissection. This is a potentially rich source of genetic material if ova could be preserved and grown in vitro, especially from rare or endangered species that die abruptly or are ovariectomized for medical reasons. The aims of this study were to examine cryoprotectant toxicity and then the potential of successfully cryopreserving preantral cat follicles. In the initial toxicity trial, isolated cat follicles $(40-90 \mu \mathrm{m})$ were exposed to dimethylsulfoxide, glycerol, 1,2-propandiol or ethylene glycol at $0^{\circ} \mathrm{C}$ for $15 \mathrm{~min}$. Follicle viability was assessed by supravital staining using a combination of Trypan blue and Hoechst 33258 at $\mathrm{O} h$, and after $18 \mathrm{~h}$ and 1 week of culture. Percentages of follicles with intact oocytes and granulosa cells were similar $(P>0.05)$ among control (no cryoprotectant), dimethylsulfoxide, 1,2propandiol and ethylene glycol treatments at all time points, but were reduced $(P<0.05)$ after glycerol exposure. On the basis of this finding, dimethylsulfoxide and 1,2-propandiol were used to cryopreserve intact follicles, and post-thaw viability was assessed by supravital staining and 5-bromo-2'-deoxyuridine uptake into oocytes and granulosa cells during culture. Of control (noncryopreserved) follicles, $31.4 \% \pm 2.9 \%, 18.8 \% \pm 1.9 \%$ and $16.2 \% \pm 1.6 \%$ were intact after $\mathrm{Oh}, 18 \mathrm{~h}$ and $\mathrm{I}$ week of culture, respectively. Uptake of 5 -bromo-2'-deoxyuridine occurred in approximately $20 \%$ of follicles at all time points. On the basis of the presence of both a healthy oocyte and granulosa cells, cryopreservation in dimethylsulfoxide or 1,2-propandiol allowed approximately 19\% of follicles to survive. Approximately $10 \%$ demonstrated clear evidence of cell activity that was sustainable for 1 week. In conclusion, the cat ovary contains a population of preantral follicles that are not adversely affected by short-term exposure to most conventional cryoprotectants. Furthermore, there is a subpopulation of these follicles capable of surviving cryopreservation, remaining structurally intact and physiologically active after thawing.
\end{abstract}

\section{Introduction}

Cryopreservation and assisted reproduction techniques, developed to exploit the availability of germ cells in domesticated mammals, have profound potential for maintaining genetic diversity in wildlife populations living in zoos and in the wild (Wildt, 1990). Combinations of techniques such as artificial insemination, in vitro oocyte maturation (IVM), in vitro fertilization (IVF) and embryo transfer, together with gamete and embryo cryopreservation, offer unique opportunities for assisting in the management and propagation of small populations. In particular, cryopreservation of germ cells would extend the generation interval and protect the genetic diversity of valuable founder animals, making these genes available for future generations (Wildt et al., 1993).

Rescue of female germ cells from valuable animals that die abruptly or undergo ovariohysterectomy for medical reasons

*Correspondence.

Received 1 September 1997. requires the successful recovery, preservation, growth and fertilization of ovarian oocytes. The development of IVM/IVF systems for cat oocytes has been in progress for almost a decade (Goodrowe et al., 1988; Johnston et al., 1989; Lengwinat and Blottner, 1994; Wood et al., 1995; Wolfe and Wildt, 1996), and includes work with several wild felid species (Johnston et al., 1991). All of these studies have focused on antral oocytes, but the number of oocytes could be vastly increased if it was possible to recruit earlier oocyte stages. The preantral pool of primordial, primary and secondary follicles comprise $>99 \%$ of ovarian oocytes (Gougeon, 1993). Because the ovary of a fertile, adult cat contains approximately 50000 oocytes (Göritz and Jewgenow, 1993), this is a rich source of genetic material if these gametes could be collected and grown in vitro to maturity. We have developed a mechanical dissection tool for harvesting many preantral follicles from the ovaries of the domestic cat (Jewgenow and Göritz, 1995) and its wild relatives (Jewgenow and Stolte, 1996).

The required growth period for preantral rodent oocytes is $<3$ weeks (Eppig and O'Brien, 1996), but is several months for 
similar stage cattle (Lussier et al., 1987) and human (Gougeon, 1993 ) oocytes. Mouse preantral follicle-oocyte complexes can be grown in vitro and the oocytes recovered, successfully matured, fertilized in vitro and then used to produce young after embryo transfer (Eppig and Schroeder, 1989; Eppig and O'Brien, 1996). Mouse preantral follicles also have been cryopreserved successfully as demonstrated by the production of live young after IVM, IVF and embryo transfer (Carroll et al., 1990).

We anticipate that a practical and comprehensive gamete rescue programme for felids will involve long-term culture for growth, as well as an ability to cryopreserve freshly collected oocytes. Therefore, as a first step to achieving this long-term goal, the objectives of this study were: (1) to determine the ability to recover and sustain preantral cat follicles in vitro for as long as I week; and (2) to examine the influence of four common cryoprotectants (dimethylsulfoxide (DMSO), glycerol (GLYC), 1,2-propandiol (PROH) and ethylene glycol (ETOH)) on follicle viability at a chilling temperature, and the effects of DMSO and PROH on the viability of follicles after cryopreservation. Because the follicle complex comprises an oocyte and granulosa cells, a secondary aim was to determine the need to use a multiple evaluative approach to ensure accurate estimation of viability in terms of plasma membrane integrity and cell proliferation.

\section{Materials and Methods}

\section{Follicle recovery}

Ovaries were obtained from domestic cats ovariohysterectomized at local veterinary clinics. The exact age and reproductive history of each donor almost always was unknown; however, most donors were 12-24 months old and believed nulliparous. After excision, ovaries were placed into $50 \mathrm{ml}$ centrifuge tubes (Corning Glass Works, Corning, NY) containing $15 \mathrm{ml} \mathrm{PBS}$, stored at $4^{\circ} \mathrm{C}$ and then processed within $24 \mathrm{~h}$. Number of follicles (recovery) and viability (see below) were evaluated on the basis of cool ovarian storage for one of two time periods: $<12 \mathrm{~h}$ or $12-24 \mathrm{~h}$.

After being washed, ovaries were dissected to recover oocytes from antral follicles and these were used in another unrelated study. The dissection procedure for antral follicles is described by Wolfe and Wildt (1996). Ovaries then were carefully pressed through a cell dissociation sieve $(60$ mesh, Sigma Chemie $\mathrm{GmbH}$, Deisenhofen) together with $20 \mathrm{ml}$ Hepes buffered Minimum Essential Medium (MEM; Gibco Laboratories, Grand Island, NY) containing $3 \mathrm{mg} \mathrm{BSA} \mathrm{ml}^{-1}$ (Sigma Chemical Company, St Louis, MO; A-9418, lot $53 \mathrm{H} 00685)$, hereafter referred to as HMEM. The resulting cell suspension was passed through a series of nylon sieves ( $100 \mu \mathrm{m}$ and $40 \mu \mathrm{m}$ cell strainers; Falcon, Becton Dickinson Labware, Franklin Lakes, NJ). The $40 \mu \mathrm{m}$ cell strainer was rinsed in $10 \mathrm{ml}$ HMEM allowing the recovery of all follicles with a diameter of $40-90 \mu \mathrm{m}$. This follicle suspension (a composite of 2-4 ovaries processed together) consisted of a combination of primordial and primary (80-90\%) and small secondary follicles (Jewgenow and Göritz, 1995). The suspension was centrifuged at $300 \mathrm{~g}$ for $5 \mathrm{~min}$ and resuspended in $1 \mathrm{ml} \mathrm{MEM} \mathrm{(Sigma)}$ containing Earle's saits, $30 \mathrm{iu}$ streptomycin $\mathrm{ml}^{-1}, 120 \mathrm{iu}$ peni-

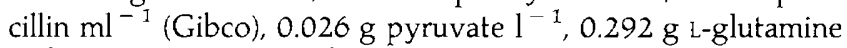
$\mathrm{l}^{-1}$ and $3 \mathrm{mg} \mathrm{BSA} \mathrm{ml}^{-1}$ (Sigma). A $20 \mu \mathrm{l}$ aliquot was taken for counting the number of follicles.

\section{In vitro culture of small preantral follicles}

By adding MEM, follicle concentration was adjusted to $1000 \mathrm{ml}^{-1}$, and approximately 200 follicles (approximately $200 \mu \mathrm{l})$ were transferred into each well of a series of fourwell culture dishes (Nunc, Roskilde) containing $300 \mu \mathrm{I}$ MEM covered with mineral oil (Sigma). Follicles were cultured at $38^{\circ} \mathrm{C}$ in $5 \% \mathrm{CO}_{2}$ in air in a standard laboratory incubator. Random aliquots of follicles were removed immediately before culture $(0 \mathrm{~h})$ or after an $18 \mathrm{~h}$ or 1 week incubation, and were then assessed for viability.

\section{Viability assessment}

Viability assessment of follicle cells was performed using two supravital stains, Trypan blue (TB, Sigma) and Hoechst 33258 (H58, Sigma). Both stains have proved useful for characterization of cell membrane integrity by dye exclusion from vital cells (Trypan blue: Phillips, 1973; Hoechst 33258: Singh and Stephens, 1986). In a preliminary experiment, aliquots of preantral follicle populations with presumed high (immediately after isolation) and low (killing follicles by heating and cooling) viability were stained using Trypan blue and Hoechst 33258 separately. The percentage of dead (fully stained) follicles was confirmed with Trypan blue and Hoechst 33258 ( $n=25 ; P<0.05$; viability range, $0-60 \%$ ). Owing to their complex structure, many follicles were partially stained (intermediate stages). For enhanced differentiation of these intermediate stages, the combination of Trypan blue and Hoechst staining was used to take advantage of the different staining pattern (Trypan blue is enriched in the cytoplasm and Hoechst 33258 binds to the DNA of dead cells; Phillips, 1973; Singh and Stephens, 1986).

In the present study, the combined viability staining was used as follows. A $50 \mu \mathrm{l}$ aliquot containing preantral follicles was collected from each culture well and was supplemented with $0.5 \mu \mathrm{l}$ Hoechst 33258 stock solution in PBS ( $1 \mathrm{mg} \mathrm{ml}^{-1}$ ) for $15 \mathrm{~min}$ at $38^{\circ} \mathrm{C}$. This step was followed by adding $2.5 \mu \mathrm{l}$ $0.4 \%$ Trypan blue solution for $1 \mathrm{~min}$. The aliquot then was mounted on a slide, and each follicle was evaluated under phase contrast and fluorescence excitation using a Leitz Diaplan microscope (Leica, Wetzlar). Follicles were categorized into one of five viability classes (Fig. 1): I, follicies with $0-3$ granulosa cells $(<10 \%)$ stained with Trypan blue and with no visible germinal vesicle within the oocyte; II, follicles with 4-15 granulosa cells (10-50\%) stained and with no visible germinal vesicle within the oocyte; III, follicles with $0-3$ granulosa cells $(<10 \%)$ stained and with a visible germinal vesicle (detectable by Hoechst treatment); IV, follicles with 4-15 granulosa cells $(10-50 \%)$ stained and with a visible germinal vesicle; $\mathrm{V}$, follicles in which $>50 \%$ of the granulosa cells stained. Follicles 
categorized as class I or II were considered to contain viable oocytes, whereas class I and III follicles were considered to contain viable granulosa cells.

\section{Incorporation of 5-bromo-2'-deoxyuridine as an index of DNA synthesis}

At $0 \mathrm{~h}, 18 \mathrm{~h}$ and 1 week of culture, follicles were supplemented for an additional $12 \mathrm{~h}$ with $10 \mu \mathrm{l}$ 5-bromo-2'-deoxyuridine (BrdU) labelling reagent $\left(0.5 \mathrm{mmol} \mathrm{1}^{-1}\right.$; BrdU-Kit II; Boehringer Mannheim Biochemica, Mannheim). After incubation, follicles were transferred into siliconized glass tubes containing $10 \mathrm{ml}$ washing buffer (BrdU-Kit II), centrifuged at $300 \mathrm{~g}$ for $5 \mathrm{~min}$, and resuspended in $50 \mu \mathrm{l}$ buffer. All follicles were mounted on a glass slide and air-dried. Cells were fixed in $70 \%$ ethanol (in glycine buffer, $50 \mathrm{mmol} \mathrm{l}^{-1}$; $\mathrm{pH} \mathrm{2.0)}$ ) for at least $20 \mathrm{~min}$ at $-20^{\circ} \mathrm{C}$. Further steps were performed according to the assay procedure described in the Boehringer Kit. In brief, slides were washed and subsequently covered with anti-BrdU- and anti-mouse-IgG-alkaline phosphatase working solutions $\left(30 \mathrm{~min}, 37.5^{\circ} \mathrm{C}\right.$ ). The substrate reaction was visible $30 \mathrm{~min}$ after adding the colour substrate solution. Slides were covered with glycerol-gelatin and evaluated under a light microscope at a magnification of $\times 100$. Preantral follicles that incorporated $\mathrm{BrdU}$ into nuclei were considered to have proliferating cells. Control follicles were processed without adding BrdU to the culture medium $(n=400)$ and by heat-treating follicles $\left(75^{\circ} \mathrm{C}\right.$ for $\left.20 \mathrm{~min} ; n=400\right)$.

\section{Cryoprotectant toxicity}

The sources and concentration of the various cryoprotectant solutions were as follows: $1.5{\mathrm{~mol} \mathrm{DMSO} \mathrm{l}^{-1} \text { (DOMOSO }}^{\mathrm{R}}$, Syntex Animal Health, West Des Moines, IA); 10\% (v/v)

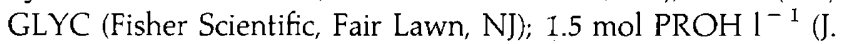

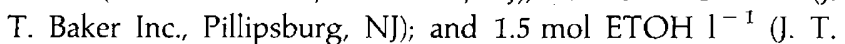
Baker). All cryoprotectants were prepared at a twofold concentration in HMEM with $20 \%(\mathrm{v} / \mathrm{v})$ fetal calf serum (Sigma). Aliquots $(200 \mu \mathrm{l})$ of follicle suspension were transferred to $1.8 \mathrm{ml}$ Eppendorf tubes and cooled in ice water $\left(0-1^{\circ} \mathrm{C}\right)$ for $10 \mathrm{~min}$ before adding an equal volume of ice-cold cryoprotectant. Follicles were left to equilibrate in each cryoprotectant at $0^{\circ} \mathrm{C}$ for an additional $15 \mathrm{~min}$. Tubes then were warmed by shaking in a $37^{\circ} \mathrm{C}$ water bath for $1 \mathrm{~min}$. Cryoprotectant was removed by adding $400 \mu \mathrm{l}$ HMEM twice at room temperature followed each time by a $5 \mathrm{~min}$ incubation. Diluted follicle suspensions were centrifuged at $300 \mathrm{~g}$ for $2 \mathrm{~min}$, washed with $1 \mathrm{ml}$ HMEM and finally resuspended in $200 \mu \mathrm{l}$ culture medium. Follicles were counted, and viability was estimated using Trypan blue-Hoechst-staining after $0 \mathrm{~h}, 18 \mathrm{~h}$ and 1 week of culture. Controls consisted of follicles to which HMEM was added, without cooling to $0^{\circ} \mathrm{C}$ (hereafter called FRESH) and with cooling to $0^{\circ} \mathrm{C}$ and incubation for $15 \mathrm{~min}$ at $0^{\circ} \mathrm{C}$ (hereafter called (COOL). Control follicles were washed as described above before assessing viability.

\section{Follicle cryopreservation and thawing}

On the basis of findings from the toxicity experiment above and earlier results from freezing cat embryos and preantral follicles (Pope et al., 1994; Jewgenow and Göritz, 1995), DMSO and PROH were selected for the cryopreservation trial. Follicle samples $(200 \mu \mathrm{l})$ were transferred into $1.8 \mathrm{ml}$ Eppendorf tubes and placed in ice water for $10 \mathrm{~min}$. An equal volume $(200 \mu \mathrm{l})$ of ice-cold $\left(0^{\circ} \mathrm{C}\right)$ twofold cryoprotectant was added slowly, and the vial was equilibrated at $0^{\circ} \mathrm{C}$ for $15 \mathrm{~min}$. Samples were transferred into $0.25 \mathrm{ml}$ plastic straws, sealed and cooled slowly at $0.5^{\circ} \mathrm{C} \mathrm{min}{ }^{-1}$ (Biocool, FTS Systems Inc., Stone Ridge, NY). After seeding at $-7^{\circ} \mathrm{C}$, straws were cooled further to $-70^{\circ} \mathrm{C}$ at $0.5^{\circ} \mathrm{C} \mathrm{min}{ }^{-1}$ before being plunged into liquid nitrogen $\left(-196^{\circ} \mathrm{C}\right)$ for a minimum of $24 \mathrm{~h}$.

Straws were thawed rapidly in a water bath $\left(37^{\circ} \mathrm{C}\right.$, approximately $2500^{\circ} \mathrm{C} \mathrm{min}{ }^{-1}$ ) for $1 \mathrm{~min}$. Each follicle suspension (two straws) was flushed into an Eppendorf tube with $200 \mu \mathrm{l}$ HMEM per straw, diluted by adding $400 \mu$ l HMEM at room temperature followed each time by a $5 \mathrm{~min}$ incubation. After centrifugation at $300 \mathrm{~g}$ for $5 \mathrm{~min}$, follicles were washed with $1 \mathrm{ml}$ HMEM and resuspended in $100 \mu \mathrm{l}$ of culture medium, counted and aliquots were stained for viability or cultured for testing in vitro DNA synthesis.

\section{Statistical analyses}

Mean \pm SEM values are presented. Data were analysed using a multi-way analysis of variance (MANOVA). For calculating significant differences among test groups in the toxicity $(6 \times 3$ matrix) and cryopreservation $(3 \times 3$ matrix $)$ trials, the LCD test for planned comparison ( $t$ test for dependent samples) was applied. All statistical procedures were performed with the software program Statistika for Windows (Release 4.5, copyright StatSoft Inc., 1993).

\section{Results}

\section{Recovery and culture of preantral follicles}

Ovaries from 52 queens were subjected to mechanical isolation, resulting in an average of $1472 \pm 288$ small (40$90 \mu \mathrm{m}$ diameter) preantral follicles recovered per ovary. On the basis of the separate viability assessments of oocytes and granulosa cells, different classes of harvestable preantral follicles were found in the cat ovary. Follicles were considered to be healthy if they contained both a viable oocyte and granulosa cells (class I). All other classes were compromised either by a poor oocyte or by poor granulosa cells, or both (Fig. 1). The number of healthy follicles depended on the length of cold ovarian storage before dissection (Table 1). When ovaries were processed on the day of ovariohysterectomy ( $<12 \mathrm{~h}$ storage), the percentage of intact follicles with viable oocytes and granulosa cells (class I) was $>10 \%$ greater $(P<0.05)$ than for ovaries stored for $12-24 \mathrm{~h}$. However, by 1 week of culture, the percentage viability was similar between the groups.

\section{Cryoprotectant toxicity assessment}

Trypan blue combined with Hoechst staining allowed the effective independent assessment of cryoprotectant effects on 

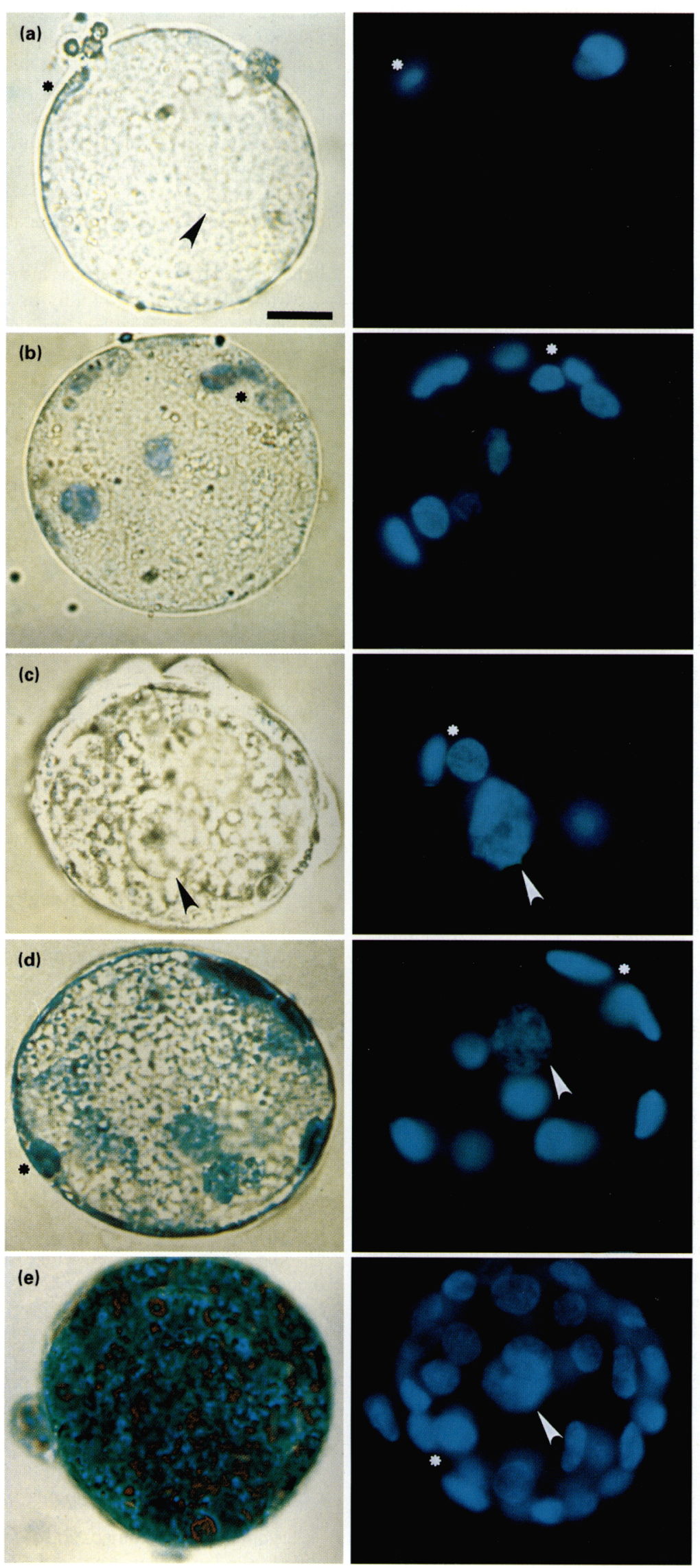
Table 1. Recovery and viability of preantral follicles $40-90 \mu \mathrm{m}$ in diameter from domestic cat ovaries after storage for $<12 \mathrm{~h}$ and $12-24 \mathrm{~h}$ at $4^{\circ} \mathrm{C}$

\begin{tabular}{|c|c|c|c|c|}
\hline \multirow{2}{*}{$\begin{array}{l}\text { Ovarian } \\
\text { storage } \\
\text { interval } \\
\text { (h) }\end{array}$} & \multirow[b]{2}{*}{$\begin{array}{c}\text { Number of } \\
\text { ovaries }\end{array}$} & \multirow{2}{*}{$\begin{array}{l}\text { Number of } \\
\text { follicles } \\
\text { per ovary }\end{array}$} & \multicolumn{2}{|c|}{$\begin{array}{l}\text { Percentage viable (class I) } \\
\text { preantral follicles after }\end{array}$} \\
\hline & & & $\begin{array}{l}\text { Immediate } \\
\text { isolation }\end{array}$ & $\begin{array}{l}1 \text { week } \\
\text { culture }\end{array}$ \\
\hline$<12$ & 32 & $1622 \pm 289$ & $42.3 \pm 3.5^{\mathrm{a}}$ & $22.5 \pm 1.8$ \\
\hline $12-24$ & 72 & $1269 \pm 808$ & $31.7 \pm 1.8^{\mathrm{b}}$ & $18.5 \pm 2.7$ \\
\hline
\end{tabular}

${ }^{a, b}$ Different superscripts within columns indicate significantly different values $(P<0.05)$.

oocyte and granulosa cell integrity (Table 2, Fig. 1). Follicle culture always resulted in a decrease $(P<0.05)$ in overall viability of oocytes and granulosa cells with time $(0 \mathrm{~h}$ versus $18 \mathrm{~h}$ versus I week; Table 2). Decline in viability affected only the oocyte, since there was no obvious effect on class III follicles in which granulosa cells remained healthy. Approximately $5 \%$ of all preantral follicles contained a healthy oocyte but poor granulosa cells (class II), whereas approximately $12 \%$ contained a poor oocyte but viable granulosa cells (class III) During the I week culture, class II follicles (with unhealthy granulosa cells) were not sustained. In contrast, class III follicles (dead oocyte inside a viable granulosa cell layer) tended to survive (Table 2).

Cooling follicles to $0^{\circ} \mathrm{C}$ for $15 \mathrm{~min}$ did not reduce $(P>0.05)$ the number of healthy (class I) follicles. However, follicles with partly affected granulosa cells (class II and IV) could not withstand low temperature and died $(P<0.05)$. Adding DMSO, PROH or ETOH did not result in further loss of viability compared with FRESH controls. However, supplementing with GLYC decreased viability by approximately $15 \%$ $(P<0.05)$ at $\mathrm{Oh}$, although this difference was not evident at $18 \mathrm{~h}$ or I week

\section{Cryopreservation of preantral follicles}

Approximately 16000 small, preantral follicles isolated from 25 cat ovaries stored $>12 \mathrm{~h}$ were cryopreserved. Upon thawing, $66.3 \pm 5.6 \%$ of these $(n=10786)$ were recovered intact, suitable for assessment and further culture. Overall, cryopreservation and thawing decreased $(P<0.05)$ the percentage of viable oocytes (class I and II follicles) regardless of cryoprotectant used (Fig. 2). Before cryopreservation, $33.9 \pm 2.7 \%$ of follicles contained viable oocytes, and $>21 \%$ experienced $\mathrm{BrdU}$ incorporation (Table 3). After thawing, $19.3 \pm 2.8 \%$ of DMSO- and $18.5 \pm 2.7 \%$ of $\mathrm{PROH}$-exposed oocytes were viable when stained with Trypan blue-Hoechst (Fig. 2). In vitro DNA synthesis occurred in $15.5 \pm 5.4 \%$ and $13.9 \pm 4.5 \%$ of these oocytes, respectively (Table 3 ). Follicular granulosa cells also were affected by cryopreservation. The percentage of follicles with viable granulosa cells (class I and III) at $\mathrm{O}$ (FRESH) was $45.1 \pm 3.7 \%$ compared with $32.6 \pm 5.6 \%$ and $28.6 \pm 5.6 \%$ for cryopreservation with DMSO and PROH, respectively $(P<0.05)$ (Fig. 2). BrdU incorporation into granulosa cells was similar $(P>0.05)$ for FRESH, DMSO and PROH treatments (mean range $18.5-24.8 \%$ ).

For FRESH, class I follicles, there was a gradual decline in oocyte/granulosa cell viability over time (Fig. 2). At $18 \mathrm{~h}$ and I week of culture, cryopreserved-thawed follicles were less viable $(P<0.05)$ than their FRESH counterparts. Nonetheless, approximately $10 \%$ of follicles cryopreserved with DMSO or PROH retained viable oocytes, and $20 \%$ contained healthy granulosa cells. In vitro DNA synthesis in oocytes or granulosa cells did not change during culture, regardless of treatment (Table 3).

Labelling of control follicles resulted in staining of fewer than $1 \%$ of oocytes and $3 \%$ of granulosa cells in the negative control (without BrdU) versus $6.8 \%$ of oocytes and $1.7 \%$ of granulosa cells in the heat-treated control (dead follicles).

\section{Discussion}

This study determined that it was feasible to cryopreserve successfully a subpopulation of small preantral follicles (40$90 \mu \mathrm{m}$ in diameter) from the domestic cat ovary. These follicles could be sustained either fresh or after freezing and thawing for as long as 1 week in vitro, and could contain both viable oocytes and granulosa cells. Because growth to a more mature (larger) stage was not expected within 1 week culture, we assessed follicle survival with cryoprotectant and cryopreservation on the basis of plasma membrane integrity and cell proliferation status. Carroll et al. (1990) reported the survival of mouse preantral follicles assessed morphologically after freezing. Because mouse preantral follicles can grow to maturity in vitro, it was possible in that study to test survival on the basis of oocyte fertilization and embryo development to term.

Fig. 1. Preantral cat follicles stained with Trypan blue (left column) and Hoechst 33258 (right column). (a) Class I follicle, no staining of germinal vesicle and $<4$ granulosa cells ( $<10 \%$ ) stained. (b) Class II follicle, unstained germinal vesicle and 4-15 granulosa cells (10-50\%) stained. (c) Class III, stained germinal vesicle (Hoechst) with $<4$ granulosa cells $(<10 \%)$ stained. (d) Class IV, germinal vesicle and 4-15 granulosa cells (10-50\%) stained. (e) Class V, staining of entire follicle. Arrowheads represent stained germinal vesicle; asterisks show stained granulosa cells; scale bar represents $10 \mu \mathrm{m}$. 


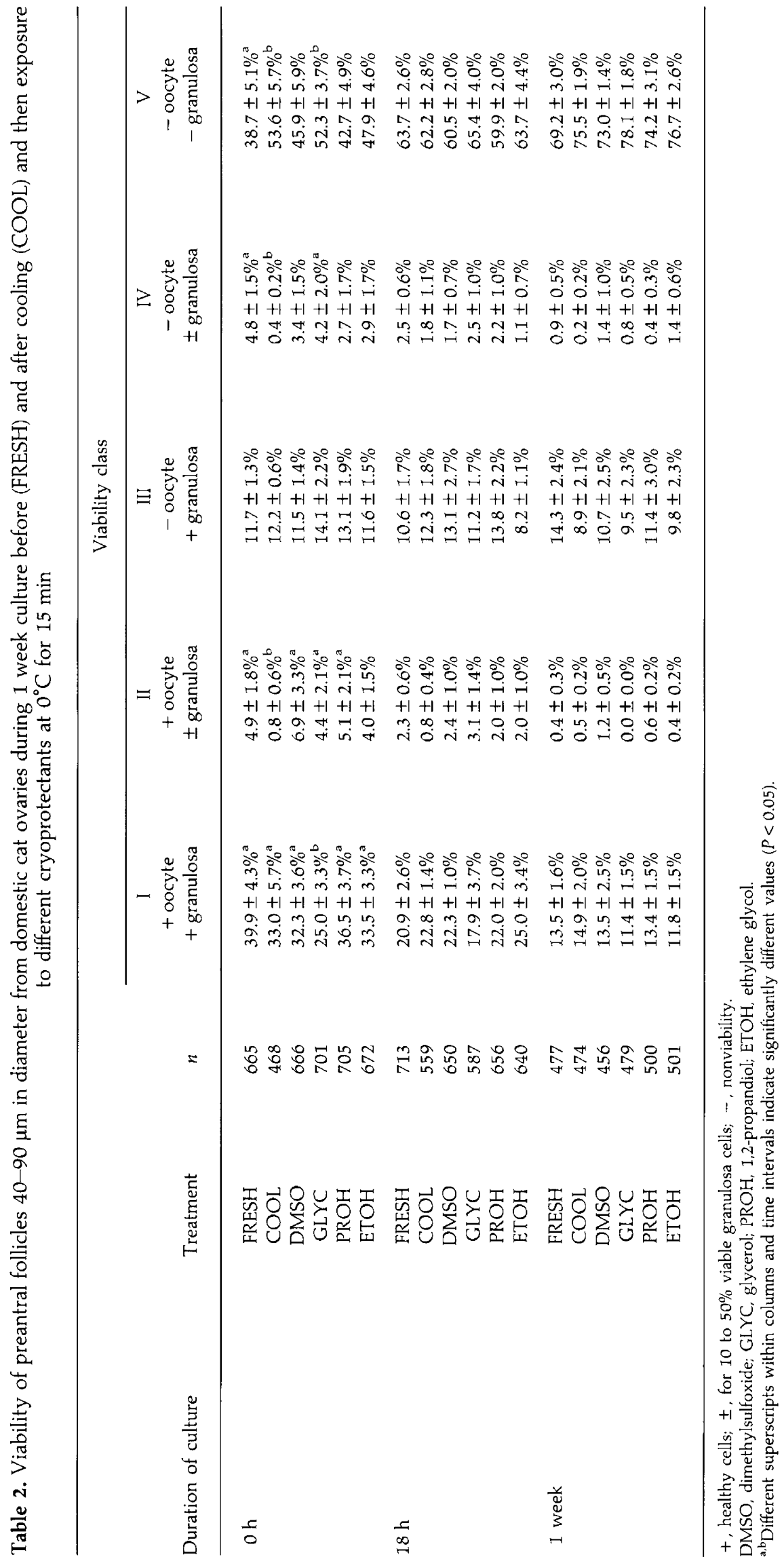




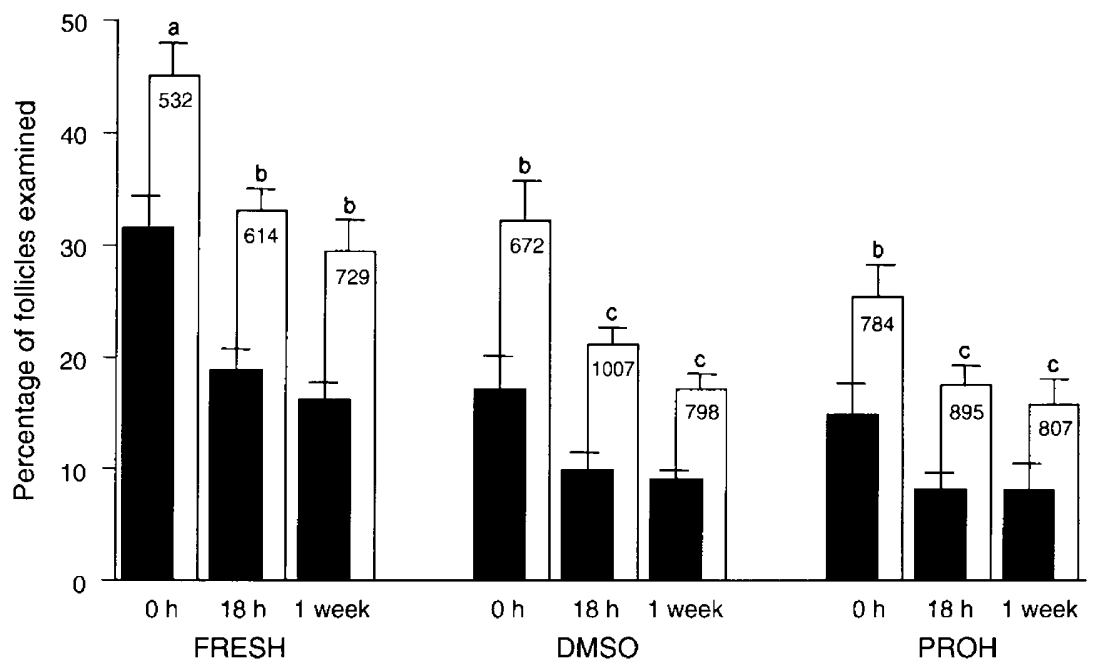

Fig. 2. Viability of preantral cat follicles during 1 week of culture in vitro assessed by combined Trypan blue-Hoechst 33258 staining. ( $\boldsymbol{\square}$ ) viable follicles (class I); ( $\square$ ) viable granulosa cells (class I and III). FRESH, untreated control follicles. DMSO and PROH include follicles previously cryopreserved in $1.5 \mathrm{~mol}$ dimethylsulfoxide $\mathrm{I}^{-1}$ (DMSO) or $1.5 \mathrm{~mol} 1,2$ propandiol $\mathrm{l}^{-1}$ ( $\mathrm{PROH}$ ). Within different main treatment groups, bars with different letters differ significantly $(P<0.05)$. Numbers within each open bar indicate total numbers of preantral follicles tested within that treatment during that time period.

Table 3. In vitro DNA synthesis in preantral follicles $40-90 \mu \mathrm{m}$ in diameter from domestic cat ovaries before (FRESH) and after cryopreservation using dimethylsulfoxide (DMSO) and 1,2-propandiol (PROH)

\begin{tabular}{lccccc}
\hline Treatment & $\begin{array}{c}\text { Time of } \\
\text { adding } \\
\text { BrdU }\end{array}$ & $\begin{array}{c}\text { Number } \\
\text { of } \\
\text { replicates }\end{array}$ & $\begin{array}{c}\text { Number } \\
\text { of } \\
\text { follicles }\end{array}$ & Oocytes & Granulosa cells \\
\hline FRESH & o h & 5 & 241 & $21.9 \pm 1.9 \%$ & $24.8 \pm 5.1 \%$ \\
& $18 \mathrm{~h}$ & 5 & 237 & $17.8 \pm 2.1 \%$ & $23.2 \pm 5.0 \%$ \\
& 1 week & 5 & 289 & $23.6 \pm 4.7 \%$ & $22.3 \pm 3.8 \%$ \\
DMSO & oh & 6 & 486 & $15.5 \pm 5.4 \%$ & $23.6 \pm 3.7 \%$ \\
& $18 \mathrm{~h}$ & 6 & 454 & $12.9 \pm 2.6 \%$ & $19.0 \pm 4.8 \%$ \\
PROH & 1 week & 5 & 383 & $16.8 \pm 3.5 \%$ & $22.8 \pm 3.7 \%$ \\
& Oh & 6 & 451 & $13.9 \pm 4.5 \%$ & $18.5 \pm 4.3 \%$ \\
& $18 \mathrm{~h}$ & 6 & 368 & $11.9 \pm 3.0 \%$ & $19.8 \pm 6.7 \%$ \\
& 1 week & 5 & 287 & $15.1 \pm 4.0 \%$ & $18.5 \pm 3.7 \%$
\end{tabular}

BrdU, 5-bromo-2'-deoxyuridine.

Oocytes from 6-day-old mice require 16 days of culture to reach the diameter and developmental competence of oocytes fully grown in vivo (Eppig and O'Brien, 1996). However, the growth period of preantral follicles from other mammals appears to be considerably longer (Gougeon, 1993), and in vitro culture of primary stage follicles to the antral stage has not yet been achieved. Long-term culture of human preantral follicles with measurable growth in diameter has been shown after 40 days culture (Zhang et al., 1995). Sirard and Coenen (1995) cultured bovine follicles for more than 3 months but, although viability was maintained, did not report follicle growth.

Immediately at collection, fewer than $50 \%$ of domestic cat preantral follicles were viable. The low post-isolation viability agreed with previous data (Jewgenow and Göritz, 1995) and is probably a result of the isolation procedure and natural amounts of atresia. Cats normally experience a high incidence of continuous follicular atresia (Wood et al., 1997). Approximately $65 \%$ of preantral follicle-oocyte complexes in cats examined histologically show clear evidence of slight or severe degeneration. In the present study, we determined that storage of ovaries for $>12 \mathrm{~h}$ resulted in an additional loss in follicle viability. In contrast, cat oocytes collected from antral follicles can be stored at $4^{\circ} \mathrm{C}$ for $24 \mathrm{~h}$ without losing the ability to mature and develop in vitro after fertilization (Wolfe and Wildt, 1996). Small preantral follicles seem to be more sensitive to prolonged cold storage than larger preantral follicles.

Combined use of the supravital stains Trypan blue and Hoechst 33258 was effective for determining overall follicle 
viability. Trypan blue staining is a means of assessing granulosa cell viability (Jewgenow and Göritz, 1995), but Hoechststaining is required to determine oocyte viability in the presence of dense granulosa cells. The unique structure of germinal vesicles meant that what could be considered the DNA of surrounding granulosa cells and the DNA of the oocytes could be distinguished. The present results confirmed that oocytes can be healthy in the presence of poor quality granulosa cells, and that granulosa cells can be viable in the presence of a dead or dying oocyte. However, a healthy follicle must contain both a viable oocyte and viable granulosa cells (Bachvarova et al., 1980; Canipari et al., 1984; Salustri et al., 1993), because intact granulosa cells are important for nutrient and metabolic precursor transport (Buccione et al., 1990) and for reducing cryoinjury (Imoedemhe and Sigue, 1992). Therefore, it was intriguing that small, preantral cat follicles containing degenerate oocytes could survive I week of culture.

Successful oocyte cryopreservation was demonstrated originally by Whittingham (1977) in mice, with similar procedures applied to a few other species (for review, see Aigner et al., 1992). However, cryopreserving female germ cells has proven difficult, because mature (metaphase II) oocytes are more sensitive than embryos to requisite cryopreservation steps, including cooling and cryoprotectant addition and removal. Whereas cooling to $4^{\circ} \mathrm{C}$ appears to impair the meiotic spindle in most species, cryoprotectant exposure can increase zona pellucida resistance, disrupt cytoskeleton and metaphase plate organization, parthenogenetically activate thawed oocytes, and inhibit first cell division after fertilization (Trounson and Kirby, 1989; Vincent et al., 1990; Hunter et al., 1991; Garrisi and Navot, 1992; Gook et al., 1995).

To avoid such problems with mature oocytes, it may be preferable to cryopreserve immature, prophase I oocytes (Candy et al., 1994; Baka et al., 1995). These young oocytes may be less susceptible to microtubular disruptions, because most of the microtubular system remains unorganized, and the chromatin is in a decondensed form, protected by the nuclear membrane (Mattson and Albertini, 1990). However, until now, no study has examined the sensitivity of immature oocytes in isolated, preantral follicles to different cryoprotectants.

The impact of prefreezing steps (cooling, adding and diluting out cryoprotectant) on both oocyte and granulosa cell viability was also assessed. Cooling of cat preantral follicles to $0^{\circ} \mathrm{C}$ was not accompanied by a decrease in the proportion of class I (healthy) follicles. In contrast, follicles with already poor quality oocytes (class II and IV) were affected adversely by simple cooling. Additional exposure to cryoprotectant (at the concentrations tested) appeared unrelated to the ability of follicles to be sustained in vitro. The only exception was an acute negative influence of $10 \%$ glycerol, an effect that was not evident by $18 \mathrm{~h}$ of culture. Although the $0 \mathrm{~h}$ negative influence of glycerol may have had no impact on freezability, follicles were cryopreserved only in DMSO and $\mathrm{PROH}$, in part because DMSO has been used successfully for cryopreserving mouse (Carroll et al., 1990) and cat (Jewgenow and Göritz, 1995) preantral follicles and PROH has been used successfully for cat embryos (Pope et al., 1994). Approximately $15 \%$ of the cryopreserved class I oocyte-granulosa cell complexes $(50 \%$ of the non-cryopreserved controls) survived the freeze-thaw process on the basis of the multiple viability assessments used. Granulosa cells appeared to be less sensitive to the cryopreservation process than the enclosed oocyte. Nonetheless, regardless of cryoprotectant used, those follicles surviving cryopreservation were relatively consistent in their ability to maintain both the oocyte and granulosa cells through the 1 week culture interval.

Cryopreservation of feline preantral follicles would be one of several components to a gamete rescue programme for rare species. At the very least, it would provide the means to preserve genetic material from valuable individuals until a culture system, or appropriate alternative, is developed to transform preantral follicles into antral follicles. A substitute to media culture could involve microsurgical nucleus transfer from preantral follicle oocytes into oocytes of fully grown follicles. Liu et al. (1996) have demonstrated that cryopreserved primordial germ cells are competent to undergo nuclear remodelling and cleavage after nuclear transfer to enucleated pig oocytes. Another option is follicle transfer to the kidney capsule (Telfer et al., 1989), an approach that already has resulted in the recovery of viable oocytes that were fertilized and used to produce live young in mice (Carroll et al., 1990). The cryopreservation of isolated, preantral follicles followed by transplantation could be an alternative to the orthotopic transplantation of ovarian pieces (Candy et al., 1995). Gosden (1992) reported the development of cat ovaries xenografted under the kidney capsule of ovariectomized, immunodeficient mice. In this case, the feline follicles grew to maturity in 1 month. A transplantation of isolated follicles is attractive because many germinal cells can be included in a single transplant with a high likelihood of graft revascularization (Scott et al., 1981).

In conclusion, approximately 1500 preantral follicles can be recovered from a single cat ovary, and about $20 \%$ of these can be considered healthy after 1 week of in vitro culture. High quality preantral oocytes also appear resilient to exposure to conventional cryoprotectants. Furthermore, approximately $10 \%$ of cat preantral follicles remain structurally intact and metabolically active after freeze-thawing. Thus, it is estimated that at least 150 healthy cat preantral follicles with a viable germ cell can be rescued from a cat ovary stored $<12 \mathrm{~h}$ at $4^{\circ} \mathrm{C}$ after excision. If similar extrapolations can be made to other felids, then serious consideration should be given to the development of oocyte banks as another tool for helping retain genetic diversity in rare species.

The authors acknowledge T. Roth for advice, the Smithsonian Institution for a short-term research award to the senior author and R. R. Hofmann for supporting the co-operation between the Institute for Zoo Biology and Wildlife Research and the Conservation and Research Center, Smithsonian Institution.

\section{References}

Aigner S, Van der Elst J, Siebzehnrübl E, Wildt L, Lang N and Van Steirteghem AC (1992) The influence of slow and ultra-rapid freezing on the organization of the meiotic spindle of the mouse oocyte Human Reproduction 7 857-864

Bachvarova R, Baran MM and Tejblum A (1980) Development of growing mouse oocytes in vitro. Journal Experimental Zoolology 211 167-170

Baka SG, Toth TL, Veeck LL, Jones HW, Muasher SJ and Lanzendorf SE (1995) Evaluation of the spindle apparatus of in vitro matured human oocytes following cryopreservation Human Reproduction 10 1816-1820 
Buccione R, Schroeder AC and Eppig IJ (1990) Interaction between somatic cells and germ cells throughout mammalian oogenesis Biology of Reproduction 43 543-547

Candy CJ, Wood MJ, Whittingham DG, Merriman JA and Choudhury N (1994) Cryopreservation of immature mouse oocytes Human Reproduction 9 17381742

Candy CJ, Wood MJ and Whittingham DG (1995) Follicular development in cryopreserved marmoset ovarian tissue after transplantation Human Reproduction 10 2334-2338

Canipari R, Palombi F, Riminucci M and Mangia F (1984) Early programming of maturation competence in mouse oogenesis Developmental Biology $\mathbf{1 0 2}$ 519-524

Carroll J, Whittingham DG, Wood MJ, Telfer E and Gosden RG (1990) Extraovarian production of mature viable mouse oocytes from frozen primary follicles Journal of Reproduction and Fertility 90 321-327

Eppig JJ and O'Brien MJ (1996) Development in vitro of mouse oocytes from primordial follicles Biology of Reproduction 54 197-207

Eppig JJ and Schroeder AC (1989) Capacity of mouse oocytes from preantral follicles to undergo embryogenesis and development to live young after growth, maturation and fertilization in vitro. Biology of Reproduction 41 $268-276$

Garrisi GJ and Navot D (1992) Cryopreservation of semen, oocytes and embryos Current Opinion in Obstetrics and Gynecology 4 726-731

Goodrowe KL, Wall RJ, O'Brien SJ, Schmidt PM and Wildt DE (1988) Developmental competence of domestic cat follicular oocytes after fertilization in vitro. Biology of Reproduction 39 355-372

Gook DA, Osborn SM and Johnston WIH (1995) Parthenogenetic activation of human oocytes following cryopreservation using 1,2-propandiol Human Reproduction $10654-658$

Göritz F and Jewgenow K (1993) Investigation of follicle dynamics in ovaries of domestic cats (Felis catus) by mechanical isolation of preantral follicles Reproduction of Domestic Animals Supplement 243

Gosden RG (1992) Transplantation of ovaries and testis. In Fetal Tissue Transplants in Medicine pp 253-279 Ed. RG Edwards. University Press, Cambridge

Gougeon A (1993) Dynamics of human follicular growth: a morphologic perspective. In The Ovary pp 21-41 Eds EY Adashi and PCK Leung. Raven Press, New York

Hunter JE, Bernard A, Fuller B, Amso N and Shaw RW (1991) Fertilization and development of the human oocyte following exposure to cryoprotectants, low temperature and cryopreservation: a comparison of two techniques Human Reproduction 6 1460-1465

Imoedemhe DG and Sigue AB (1992) Survival of human oocytes cryopreserved with or without the cumulus in 1,2-propandiol Journal of Assisted Reproduction Genetics 9 323-327

Jewgenow K and Göritz F (1995) The recovery of preantral follicles from ovaries of domestic cats and their characterisation before and after culture Animal Reproduction Science 39 285-297

Jewgenow K and Stolte M (1996) Isolation of preantral follicles from nondomestic cats - viability and ultrastructural investigations Animal Reproduction Science 44 183-193

Johnston LA, O'Brien SJ and Wildt DE (1989) In vitro maturation and fertilization of domestic cat follicular oocytes Gamete Research 24 343-356

Johnston LA, Donoghue AM, O'Brien SJ and Wildt DE (1991) Rescue and maturation in vitro of follicular oocytes collected from nondomestic felid species Biology of Reproduction 45 898-906

Lengwinat $\mathbf{T}$ and Blottner S (1994) In vitro fertilization of follicular oocytes of domestic cat using fresh and cryopreserved epididymal spermatozoa Animal Reproduction Science 35 291-301
Liu L, Moor RM, Laurie S and Notarianni E (1996) Nuclear remodelling and early development in cryopreserved, porcine primordial germ cells following nuclear transfer into in vitro matured oocytes International journal of Developmental Biology 39 639-644

Lussier JP, Matton P and Duffour JJ (1987) Growth rates of follicles in the ovary of the cow Journal of Reproduction and Fertility 81 301-307

Mattson BA and Albertini DF (1990) Oogenesis: chromatin and microtubule dynamics during meiotic prophase Molecular Reproduction and Development $25 \quad 374-383$

Phillips HJ (1973) Dye exclusion tests for cells viability. In Tissue Culture Methods and Applications pp 406-408 Eds PP Kruse and MK Patterson. Academic Press, New York

Pope CE, McRae MA, Plair BL, Keller GL and Dresser BL (1994) Successful in vitro and in vivo development of in vitro fertilized two-to four-cell cat embryos following cryopreservation, culture and transfer Theriogenology 42 513-525

Salustri A, Hascall VC, Camaioni A and Yanagishita M (1993) Oocyte granulosa cell interaction. In The Ovary pp 209-225 Eds EY Adashi and PCK Leung. Raven Press, New York

Scott JR, Keye WR, Poulson AM and Reynolds WA (1981) Microsurgical ovarian transplantation in the primate Fertility and Sterility 36 512-515

Singh NP and R.E. Stephens RE (1986) A novel technique for viable cell determinations Stain Technology 61/5 315-318

Sirard MA and Coenen K (1995) The effect of extraction conditions on the yield of primordial, primary and secondary follicies from bovine foetal ovaries and their subsequent survival in culture Biology of Reproduction Supplement 52103

Telfer E, Torrance C and Gosden RG (1989) Morphological study of cultured preantral follicles of mice after transplantation under the kidney capsule Journal of Reproduction and Fertility 89 561-565

Trounson A and Kirby C (1989) Problems in the cryopreservation of unfertilized eggs by slow cooling in dimethyl sulfoxide Fertility and Sterility $\mathbf{5 2}$ 778-786

Vincent C, Pickering SJ and Johnson MH (1990) The hardening effect of dimethylsulphoxide on the mouse zona pellucida requires the presence of an oocyte and is associated with reduction in the cortical granules present Journal of Reproduction and Fertility 89 253-259

Whittingham DG (1977) Fertilization in vitro and development to term of unfertilized mouse oocytes previously stored at $-196^{\circ} \mathrm{C}$ Journal of Reproduction and Fertility 49 89-94

Wildt DE (1990) Potential application of IVF technology for species conservation. In Fertilization in Mammals pp 349-364 Eds BD Bavister, J Cummins and ERS Roldan. Serono Symposium, USA, Norwell, Massachusetts

Wildt DE, Seal US and Rall WF (1993) Genetic Recource Banks and Reproductive Technology for Wildlife Conservation. In Genetic Conservation of Salmonid Fishes pp 159-173 Eds JG Cloud and GH Thorgaard. Plenum Press, New York

Wolfe BA and Wildt DE (1996) Development to blastocysts from in vitro maturation and fertilization of domestic cat oocytes after prolonged cold storage Journal of Reproduction and Fertility 106 135-141

Wood TC, Byers AP, Jennette BE and Wildt DE (1995) Influence of protein and hormone supplementation on in vitro maturation and fertilization of domestic cat eggs Journal of Reproduction and Fertility 104 315-323

Wood TC, Montali RJ and Wildt DE (1997) Follicle/oocyte atresia and temporal taphonomy in cold-stored domestic cat ovaries Molecular Reproduction and Development 46 190-200

Zhang J, Lui J, Xu KP, Liu B and DiMattina M (1995) Extracorporal development and ultrarapid freezing of human fetal ova journal of Assisted Reproduction and Genetics 12 361-368 